\title{
PERLOMBAAN FESTIVAL ANAK SHOLEH MASJID AL- HIDAYAH SEBAGAI UPAYA UNTUK MENUMBUHKAN KREATIVITAS DAN MENINGKATKAN PARTISIPASI WARGA PERUMAHAN PERWITA REGENCY
}

\author{
Oleh: Kurnia Dewy Anggraeni \\ dan Mahasiswa KKN Alternatif 56 Divisi I.B.1 \\ Universitas Ahmad Dahlan Yogyakarta
}

\section{Ringkasan}

Permasalahan yang ditemukan terkait dengan partisipasi warga terutama remaja dan anakanak di Perum Perwita Regency, Salakan, Bangunharjo, Sewon adalah kurang adanya wadah untuk mengasah kreatifitas dan jiwa bersosialisasi khususnya untuk remaja dan anak-anak, oleh karena itu KKN UAD menyelenggarakan kegiatan yang bertujuan untuk mendidik dan melatih kreatifitas yang berfokus kepada perkembangan anak-anak di Perum Perwita Regency. Dampak dari kegiatan KKN di lokasi ini adalah: 1). Terwujudnya kesadaran dari orang tua atau warga akan pentingnya sarana atau wadah untuk memunculkan minat yang tinggi untuk berpartisipasi dari warga, remaja dan anakanak di sekitar lokasi KKN 2). Memberikan pengalaman baru bagi warga khususnya anak-anak untuk terus berusaha berlomba-lomba dalam kebaikan 3). Menumbuhakan rasa semangat untuk terus menyelenggarakan kegiatan-kegiatan yang dapat menarik perhatian dan minat bagi warga di Perum Perwita regency.

Kata Kunci: Anak Sholeh, Kreatifitas, Perlombaan

\begin{abstract}
Abstrak
The problems that are found related to the participation of the citizens, especially adolescents and children in Perum Perwita Regency, Salakan, Bangunharjo, Sewon is the lack of containers to hone creativity and social spirit especially for adolescents and children, therefore KKN UAD organizes activities aimed at to educate and train the children-focused creativity at Perum Perwita Regency. The impact of KKN's activities in this location is: 1). The realization of the awareness of parents or citizens of the importance of facilities or containers to generate high interest to participate from citizens, teenagers and children around the location of KKN 2). Provide new experiences for the people especially children to keep trying to compete in goodness 3). Growing a sense of spirit to continue to organize activities that can attract attention and interest for citizens in Perum Perwita regency.
\end{abstract}

Keywords: Sholeh Children, Creativity, Race

\section{A. PENDAhULUAN}

Perum Perwita Regency adalah perumahan yang berada di dusun Salakan. Perumahan ini merupakan perumahan yang terbuka untuk umum, terlebih sangat terbuka untuk kegiatan-kegiatan yang dapat memakmurkan masjid Al-Hidayah yang berada di dalam perumahan. Berbagai kegiatan positif selalu diselenggarakan oleh pengurus masjid Al-Hidayah setiap minggunya dan mendapat perhatian bukan hanya dari warga perumahan tetapi juga dari warga di luar perumahan. Hingga saat ini terutama pada tingkat antusiasme warga perumahan sendiri sangat rendah dibanding warga diluar perumahan, dan hal ini menjadi masalah dari waktu ke waktu yang dialami warga di Perum Perwita Regency. 
Berbagai permasalahan yang ditemukan terkait dengan antusiasme warga terutama remaja dan anak-anak di Perum Perwita Regency, Kecamatan Sewon adalah: 1). Kurang adanya kegiatan dan sarana kreatif bagi remaja dan anak-anak di Perum Perwita Regency 2). Tidak adanya program khusus yang ditujukan untuk remaja dan anak-anak 3). Sangat rendahnya antusiasme dan partisipasi dari warga perumahan untuk mendukung setiap kegiatan yang terselenggara di perumahan. 4). Individualisme yang masih tinggi di Perum Perwita Regency.

Kegiatan yang diselenggarakan bertujuan untuk memunculkan potensi kreatifitas yang harus dipupuk sejak dini dan kesadaran masyarakat untuk turut aktif dalam setiap kegiatan yang diselenggarakan. Untuk itu perlunya dorongan-dorongan baik dari lingkungan maupun dari setiap individu. Perlu diciptakan kondisi lingkungan yang dapat mempuk daya kreatif individu, dalam hal ini mencakup dalam arti kata luas (masyarakat, kebudayaan). Timbul dan tumbuhnya kreativitas dan selanjutnya berkembangnya suatu kreasi yang diciptakan oleh seseorang individu tidak luput dari pengaruh kebudayaan serta pengaruh masyarakat tempat individu itu hidup dan bekerja (Soemardjan, 1983).

\section{B. METODE PELAKSANAAN}

Untuk mewujudkan tujuan yang diharapkan, program KKN di lokasi Perum Perwita Regency, Dusun Salakan, Bangunharjo, Sewon dilakukan dengan cara silaturahim langsung ke rumah warga dan sosialisasi program kepada majelis taklim dan warga diluar perumahan, serta melibatkan langsung remaja di lokasi KKN. Program ini mendapatkan dukungan penuh dari warga perumahan yang mana program ini memberikan energi dan dampak positif bagi remaja dan anak-anak di lingkungan perumahan.

\section{HASIL PEMBAHASAN DAN DAMPAK}

\section{Profil Perumahan}

Perum Perwita Regemcy, Salakan, Bangunharjo, Sewon, Bantuul, yang terletak \pm 1,2 dari Kelurahan Bangunharjo, \pm 1,3 dari Kecamatan Sewon, dan $\pm 4,1 \mathrm{~km}$ dari pusat kota Yogyakarta. RT 10 Perum Perwita Regency, Dusun Salakan memiliki luas wilayah \pm 5,5 hektar. Daerah ini terdiri dari 1 RT yaitu RT 10. Secara demografis perumahan ini tidak memiliki Rukun Warga (RW) karena adanya penghapusan pemerintahan RW. Jumlah kepala keluarga RT 10187 KK dan jumlah penduduk RT 10 sekitar 748 jiwa. Mayoritas mata pencaharian dan profesi yang banyak dijalani oleh warga yang tinggal di perumahan ini adalah pengusaha, dokter, pegawai negeri sipil (PNS), pegawai swasta, pengacara, dan pensiunan.

Penghasilan setiap KK di Perum Perwita Regency tidak ditemukan kesulitan sama sekali, namun kesibukan yang padat membuat waktu warga untuk bersosialisasi dan bersilaturahmi satu sama lain banyak tersita diluar perumahan. Ditambah lagi pendidikan yang ditempuh oleh anak-anak dan remaja di perumahan ini yang panjang, membuat waktu untuk bermain bersama dilingkungan perumahan sangat minim. Hal ini menyebabkan individualisme di Perum Perwita Regency sangat tinggi. 
Diterbitkan oleh Lembaga Pengabdian kepada Masyarakat Universitas Ahmad Dahlan Yogyakarta

\section{Aktivitas KKN terkait Kreativitas}

Berdasarkan profil dan permasalahan yang ada di Perum Perwita Regency, maka mahasiswa KKN mengadakan kegiatan berupa perlombaan guna menumbuhkan kreativitas dan timbulnya minat untuk bersosialisasi di masyarakat. Perlombaan yang diselenggarakan adalah Festiva Anak Sholeh Al-Hidayah (FASA) dengan memperlombakan 4 jenis lomba, yaitu lomba adzan, lomba hafalan surat pendek, lomba mewarnai dan lomba ranking 1. Kegiatan ini mendapat dukungan penuh dari warga perumahan baik secara materil maupun non materil. Antusias warga perumahan dan warga sekitar sangat tinggi dalam mengikuti lomba serta mendapat apresiasi dari warga perumahan maupun warga diluar perumahan atas terselenggaranya kegiatan tersebut. Terbukti dengan banyaknya peserta yang mengikuti perlombaan melebihi target, yaitu 100 peserta lomba. Aktivitas perlombaan tersebut dapat dilihat pada gambar 1, 2 dan 3.

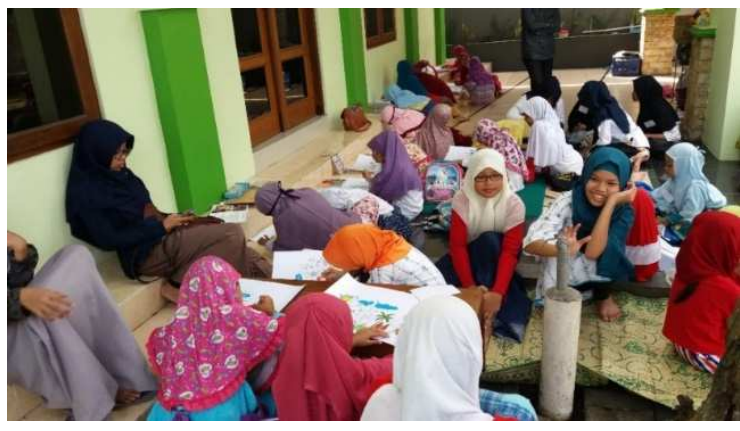

Gambar 1. Lomba Mewarnai

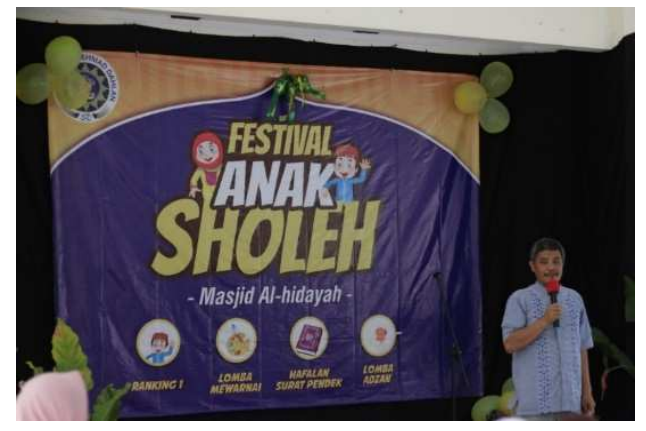

Gambar 2. Sambutan dari ketua RT 10

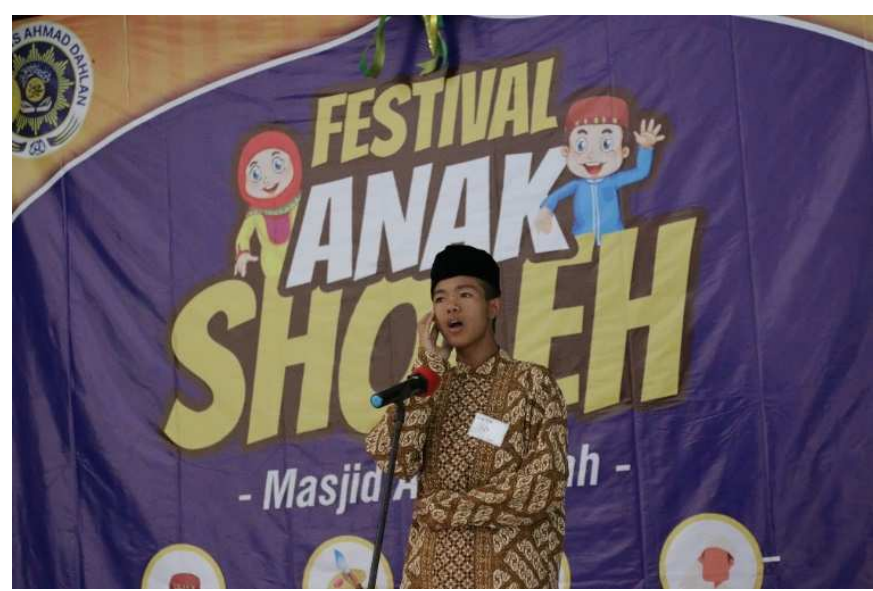

Gambar 3. Lomba Adzan 


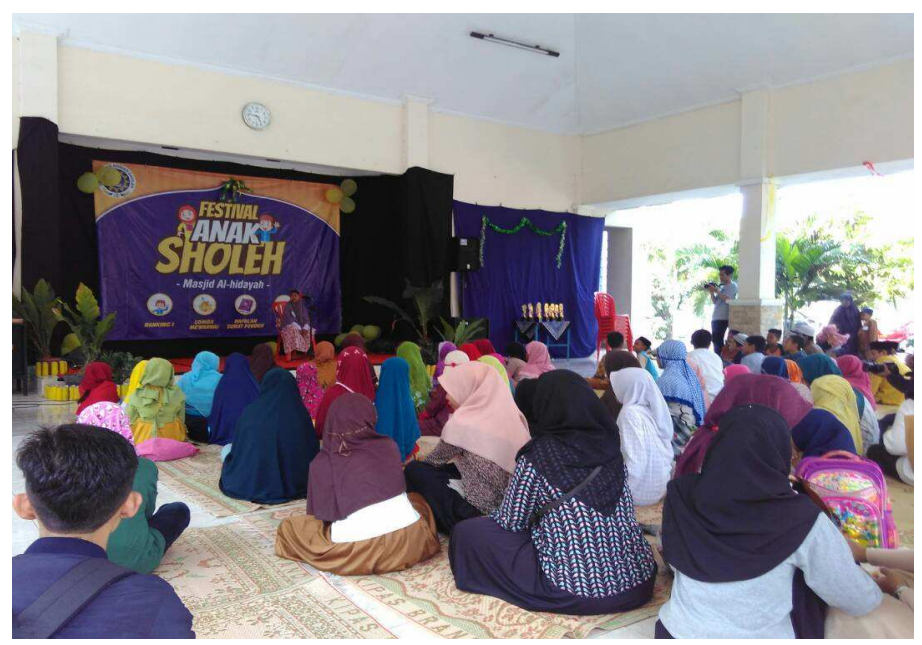

Gambar 4. Antusias Penonton

Dari gambar 1,2 dan 3 menunjukkan penerapan program KKN dalam bidang kreativitas untuk remaja dan anak-anak di Perum Perwita Regency dapat terlaksana dengan baik berkat dukungan dari semua kalangan. Dampak dari kegiatan KKN di lokasi ini adalah: 1). Terwujudnya kesadaran dari orang tua atau warga akan pentingnya sarana atau wadah untuk memunculkan minat yang tinggi untuk berpartisipasi dari warga, remaja dan anak-anak di sekitar lokasi KKN 2). Memberikan pengalaman baru bagi warga khususnya anak-anak untuk terus berusaha berlomba-lomba dalam kebaikan 3). Menumbuhakan rasa semangat untuk terus menyelenggarakan kegiatan-kegiatan yang dapat menarik perhatian dan minat bagi warga di Perum Perwita regency.

\section{KESIMPULAN}

Kegiatan KKN UAD dalam menumbuhkan kreativitas, minat dan bakat di Perum Perwita Regency telah berjalan dengan baik dan sesuai rencana program kerja.

\section{DAFTAR PUSTAKA}

Sumardjan, Selo. 1983. Kreativitas, suatu Tinjauan dari sudut Sosiologi. Jakarta: Dian Rakyat. 